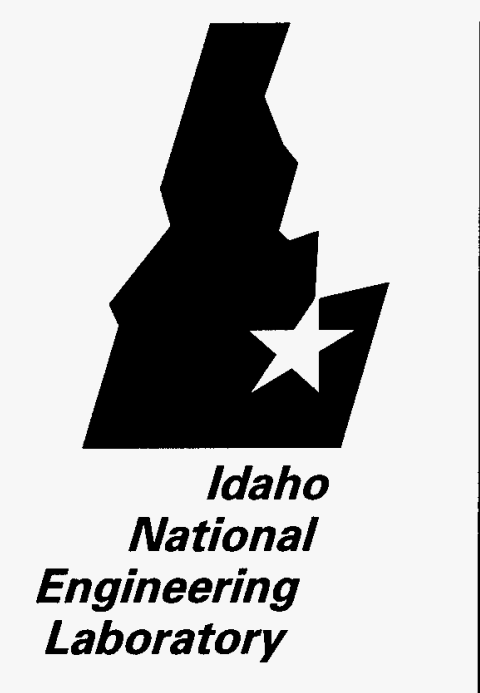

INEEL/EXT-98-00284

March 1998

\title{
National Low-Level Waste \\ Management Program Final Summary \\ Report of Key Activities and \\ Accomplishments for Fiscal Year 1997
}

\section{RECENED \\ MAR 271998 \\ OSTI}

Robert B. Rittenberg

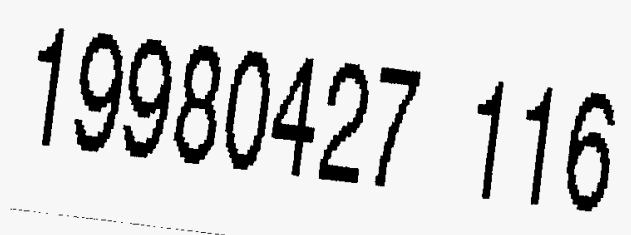

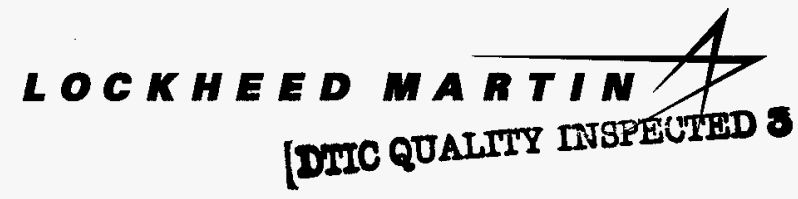




\title{
National Low-Level Waste Management Program Final Summary Report of Key Activities and Accomplishments for Fiscal Year 1997
}

\author{
Robert B. Rittenberg
}

Published March 1998

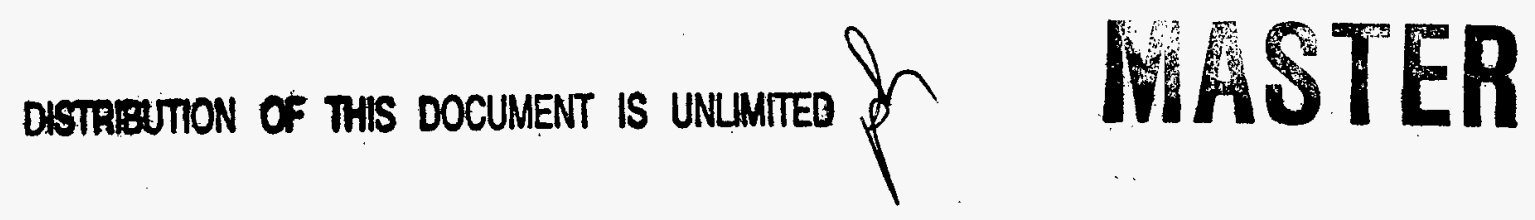

Idaho National Engineering and Environmental Laboratory

Department

Lockheed Martin Idaho Technologies Company

Idaho Falls, Idaho 83415

Prepared for the

U.S. Department of Energy

Assistant Secretary for Environmental Management

Under DOE Idaho Operations Office

Contract DE-AC07-94ID13223 


\section{DISCLAIMER}

This report was prepared as an account of work sponsored by an agency of the United States Government. Neither the United States Government nor any agency thereof, nor any of their employees, makes any warranty, express or implied, or assumes any legal liability or responsibility for the accuracy, completeness, or usefulness of any information, apparatus, product, or process disclosed, or represents that its use would not infringe privately owned rights. Reference berein to any specirie commercial product, process, or service by trade name, trademark, manufacturer, or otherwise does not necessarily constitute or imply its endorsement, recommendation, or favoring by the United States Government or any agency thereof. The views and opinions of authors expressed herein do not necessarily state or reflect those of the United States Government or.any agency thereof. 


\begin{abstract}
The U.S. Department of Energy (DOE) has responsibilities under the Low-Level Radioactive Waste Policy Amendments Act of 1985 to assist states and compacts in their siting and licensing efforts for low-level radioactive waste disposal facilities. The National Low-Level Waste Management Program (NLLWMP) is the element of the DOE that performs the key support activities under the Act. The NLLWMP's activities are driven by the needs of the states and compacts as they prepare to manage their low-level waste under the Act. Other work is added during the fiscal year as necessary to accommodate new requests brought on by status changes in states' and compacts' siting and licensing efforts. This report summarizes the activities and accomplishments of the NLLWMP during FY 1997.
\end{abstract}




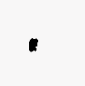




\section{CONTENTS}

ABSTRACT

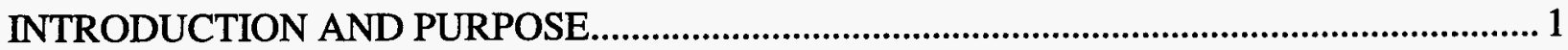

NATIONAL PROGRAM SUMMARY OF ACCOMPLISHMENTS FOR FY 1997.....................2

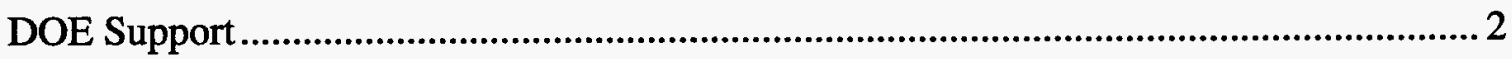

Specific Technical Assistance ......................................................................................

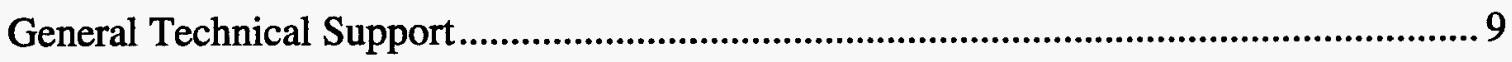

GTCC LLW Program Support ....................................................................................... 13

APPENDIX A. National Program Work Package Cost Summary...............................................15 


\section{National Low-Level Waste Management Program Final Summary Report of Key Activities and Accomplishments for Fiscal Year 1997}

\section{INTRODUCTION AND PURPOSE}

The U. S. Department of Energy (DOE) has responsibilities under the Low-Level Radioactive Waste Policy Amendments Act of 1985 (LLWPAA) to assist states and compacts in their siting and licensing efforts for low-level radioactive waste disposal facilities. The National Low-Level Waste Management Program (NLLWMP) is the element of the DOE that performs the key support activities under the Act. The NLLWMP's activities are driven by the needs of the states and compacts as they prepare to manage their low-level waste under the Act. Additional work is performed by the NLLWMP during the fiscal year as necessary to accomplish programmatic goals and to accommodate status changes in states' and compacts' siting and licensing efforts. This report summarizes the activities and accomplishments of the NLLWMP during fiscal year 1997.

The NLLWMP has three principal objectives. The first is to provide technical assistance to states and compact regions in developing new commercial low-level radioactive waste disposal capacity in accordance with the LLRWPAA. The second objective is to assist DOE in providing safe and efficient management and disposal of Greater-Than-Class $\mathrm{C}$ low-level radioactive waste (GTCC LLW) generated by licensees of the Nuclear Regulatory Commission (NRC) and Agreement states. The third is to provide assistance to DOE in meeting its reporting requirements to Congress and to maintain a complete national perspective that enables the Department to respond to public inquiries.

Activities of the National Program are divided into four major categories or work packages: General Technical Support, DOE Support, Specific Technical Assistance, and Greater-ThanClass-C Program management. Details of the activities conducted within each work package are described later in this report.

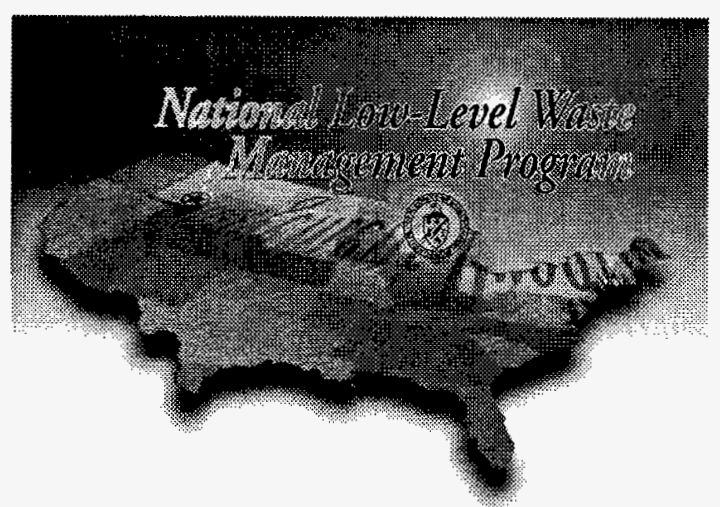




\section{NATIONAL PROGRAM SUMMARY OF ACCOMPLISHMENTS FOR FISCAL YEAR 1997}

Significant FY 1997 accomplishments in each of the four major categories under the National Program are discussed below.

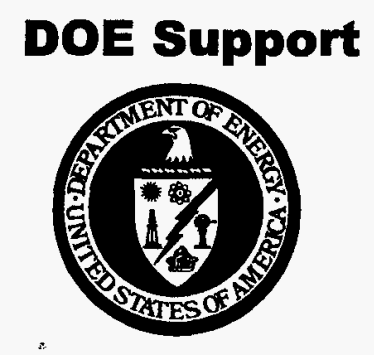

The National Program provides support to DOE on LLW issues throughout the fiscal year. The DOE's National Program fields wide ranging technical and information requests about the country's progress in managing commercial low-level radioactive waste. The DOE National Program has been providing support to the states and compacts since the passage of the LowLevel Waste Policy Amendments Act of 1985. The experience and information resources possessed by the Program are effective tools for the DOE to use in managing information requests, technology interchanges, and technical conferences. States, compacts, and other regulatory agencies have come to rely exclusively on the DOE for their policy and technical information about low-level waste. During FY 1997 the Program performed the following supporting tasks:

- The National Program organized and conducted the 18th DOE Low-Level Radioactive Waste Management Conference on May 20-22, 1997 in Salt Lake City, Utah. Approximately 280 individuals representing DOE-HQ, management and operations contractors, State and regional compacts, special interest groups, universities, nuclear utilities, and low-level waste consultants attended the conference. The conference provided an opportunity for professionals involved in managing both commercial and DOE LLW to discuss items of mutual concern. Topics included performance assessment, GTCC LLW, public acceptance considerations, waste treatment, licensing, emerging technologies, waste minimization, mixed waste, tracking and transportation, storage, and regulatory changes.
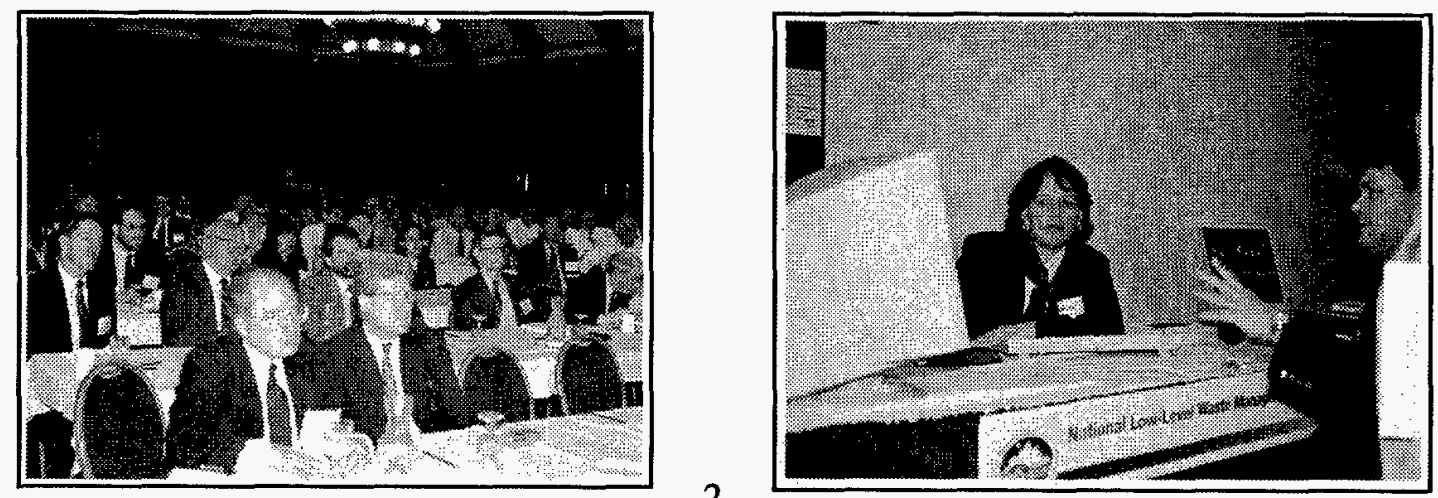
- WordPerfect text files with hypertext links from the table of contents were developed for 10 CFR 20 and 61, 49 CFR 171 and 177, and were distributed to 75 states and compact regions by the National Program's staff. Electronic copies of regulations have been requested by several state agencies and radioactive materials services vendors and fulfill a need for the timely dissemination of current regulations.

- The National Program staff prepared a Greater-than-Class-C waste presentation for DOE-HQ to present at the $13^{\text {th }}$ Annual Radioactive Waste Exchange Low-Level Radioactive Waste Management Decision-Makers Forum held on June 9-12, 1997 on Amelia Island, Florida. The briefing established the DOE's National Program as the national source of expertise on difficult radioactive waste challenges.

- National Program staff participated in the DOE Low-Level Waste Steering Committee which met in Las Vegas, Nevada, on February 25-28, 1997. The focus of the meeting was to provide final input to the LLW Program Management Plan. The Program Management Plan is the model for the DOE Complex-wide management for low-level waste. National Program staff have been recommended to be the proposed lead for the Complex-wide data call relating to Special Case Waste.

- Program staff participated in the Low-Level Waste Steering Committee meeting on November 19-21, 1996, in Albuquerque, New Mexico. The primary focus of the meeting was to provide input on DOE's Low-Level Waste Program Management Plan.

- The National Program's Document Center distributed 4,316 documents in response to special requests made by 1,666 persons. The number of requests points to a continuing strong interest in the information gathered and maintained by the Program.

- The report Summary of Expenditures for Rebates from the Low-Level Radioactive Waste Surcharge Escrow Account for Calendar Year 1996 (DOE/EM-0336) was published in June 1997.

- National Program staff assisted DOE-HQ in meeting its high priority commitments in response to the Defense Nuclear Facilities Safety Board 94-2 recommendations by providing guidance and information about managing LLW, improving the radiological assessment review and approval process, and revising the DOE's Radioactive Waste Management Order. The recommendations and revised order were submitted with supplemental information, to the Defense Board on February 28,1997 . Program staff received recognition from DOE-EM for the high-quality professional support given this project. 
- The technical report, Life-Cycle Costs for the DOE Programmatic Environmental Impact Statement (PEIS) was upgraded to final status.

- The Headquarters Cost Study for a low-level radioactive waste disposal facility similar to the Barnwell, South Carolina, facility was submitted to DOE-HQ on September 2, 1997. The Energy and Water Development Appropriations Act for fiscal year 1997 included language drafted by Senator Hollings commissioning the study to assure that the Department of Defense and the Veteran's Administration were paying equitable disposal fees.

- The Annual Report to Congress on Low-Level Radioactive Waste Management Progress was submitted to DOE-HQ ahead of schedule on January 29, 1997, meeting the National Program's cost-plus-award-fee milestone. This document summarizes national LLW management practices and progress toward development of new disposal capacity. The DOE submits this report, required by the LLRWPAA, annually to Congress.

- On behalf of DOE-HQ, National Program staff completed a side-by-side comment on the International Atomic Energy Agency's $7^{\text {th }}$ Draft of the Radwaste Convention concerning identification of waste tracking systems. DOE's involvement in the development of international standards has focused attention on the National Program's technical support capabilities.

- The National Program staff responded to 98 ad hoc requests from DOE and others. Ad hoc requests are those specific requests for information from individuals and agencies that require rapid responses to issues that have a high visibility potential. Typical ad hoc responses range from answering letters to the President about lowlevel waste issues to requests for waste treatment information from foreign governments. Ad hoc responses developed during FY 1997 include the following:

- $\quad$ The staff presented information to the South Koreans on Waste Treatment, Low-Level Radioactive Waste Management Options and Greater than Class C Wastes. This information has stimulated greater interest in the Program by the South Korean government and culminated in a speaking engagement to representatives of their regulatory agency in Seoul.

- $\quad$ Prepared a presentation for DOE to be given to a South African delegation about low-level waste management in the United States and National Program activities.

- $\quad$ Provided comments on a lengthy draft paper entitled Technical and Economic Factors Important for Developing a Regional Repository. The paper was prepared under the auspices of the International Atomic Energy Agency and discussed the possibility of establishing international, multi-regional low-level and high-level radioactive waste management facilities. 
- $\quad$ Provided comments and input to DOE-HQ on the Department of Justice's draft legal brief regarding the Central Midwest Compact Commission's suit over surcharge rebates.

- $\quad$ Submitted comment to DOE General Counsel concerning the suitability of an arid site, such as the Nevada Test Site, for LLW disposal.

Submitted an issue paper draft outline to EM-35 regarding state and compact consideration in DOE use of commercial LLW disposal facilities.

\section{Specific Technical Assistance}

The National Program develops printed information that addresses topics of general interest to states and compact regions in establishing new LLW disposal or storage capacity. The program develops, compiles, organizes, and documents related research and industry data into information modules. Such modules may be in the form of reports, handbooks, plans, or bulletins. The efforts to compile this information into usable information by states and compact regions have resulted in a sustained demand for the National Program's expertise in data reduction, meeting facilitation, and workshop sessions. The DOE's National Program is the recognized nexus of integrated information related to low-level radioactive waste management in the United States.

A selection of the technical reports, technical bulletins, and brochures disseminated by the National Program during FY 1997 are summarized below:

- National Program staff searched the Document Center's database for files and submitted them to DOE-HQ in response to a Freedom of Information Act request by Greenpeace. Answering the request required over 400 hours of staff time to compile approximately 2,000 documents.

- $\quad$ The accomplishments report entitled National Low-Level Waste Management Program Final Summary Report of Key Activities and Accomplishments for Fiscal Year 1996, INEL-96/0491 was submitted to DOE-HQ on December 19, 1996.

- The National Program published the report Performance Assessment for a Hypothetical Low-Level Waste Disposal Facility, INEL-96/0375. This document has been used extensively by states and compact regions reviewing the performance assessments submitted by prospective licensees seeking to construct low-level radioactive waste disposal facilities.

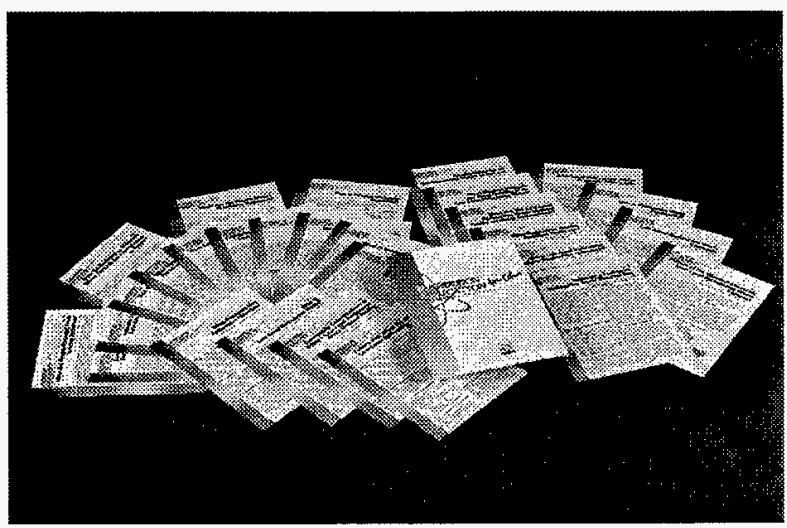


The National Program provides direct technical support by responding to specific requests, supplying technical expertise through liaisons, conducting workshops, and providing support for performance assessments.

- Program Liaison and State-Specific Requests

The National Program provides technical expertise to assist states and compact regions in conducting and reviewing LLW management activities, and provides information to Congress, states, Native American Tribal Governments, compact regions, Federal agencies, the public, and other interested parties as requested. Other objectives include maintaining contact with State and compact region representatives in order to identify technical assistance needs and monitor progress of new LLW disposal capacity development. The National Program also supports specific requests for technical assistance. Accomplishments in this area for Fiscal Year 1997 include the following:

- Program staff conducted training at the Annual Convention of Pennsylvania State Association of Township Supervisors on April 28, 1997. The training provided information to the Association members that they can use with their constituencies when discussing controversial topics such as low-level waste disposal facilities.

- National Program staff presented information on tracking low-level waste inventories and communicating radiation issues to the low-level waste generators attending the Annual Massachusetts Low-Level Waste Siting Board meeting on January 13, 1997, in Worchester, Massachusetts.

- Program staff participated in the Southeast Compact Commission's round table discussion on mechanisms for financing the completion of site development activities in North Carolina. Program staff briefed the task force on the approaches taken by other compact regions to fund their site development projects. The meeting was held on February 21, 1997, in Raleigh, North Carolina.

- The National Program held a poster session at the annual Appalachian Compact Users of Radioactive Isotopes Meeting on August 5,1997, in Harrisburg, Pennsylvania.

- $\quad$ Program staff conducted a long-range planning session with the Texas LowLevel Radioactive Waste Disposal Authority to discuss licensing protocols and procedures. This long-range planning has enabled the State of Texas to make rapid progress in these areas.

- National Program staff completed a disposal facility cost study requested by the state of New Jersey Siting Board. The study reviewed varying rates, operating periods, and continuous versus campaign style operations. The 
thrust of the study was to determine the optimum operating regimen for a disposal facility with limited waste volumes.

- National Program staff reviewed and commented on the draft Connecticut Low-Level Radioactive Waste Management Program Quality Assurance Plan. This review was performed at the request of Joe Amarello from Connecticut Hazardous Waste Management Services and was completed during the week of December 23, 1996.

- $\quad$ Liaisons developed and coordinated specialized training for staff personnel. This training focused on specific areas requested by the state and compact staffs and involved highly specialized instruction for small groups.

- $\quad$ Liaisons developed specialized research materials, such as comparisons of Host State siting criteria for distribution to states and compact region officials.

- In addition to keeping abreast of current developments and presenting updates from other states and compact regions, liaisons identified areas of potential DOE technical assistance. States and compact regions are able to access the Program's expertise more rapidly this way by avoiding a search for sources of assistance.

- $\quad$ Liaisons prepared periodic State and compact region briefs for DOE and other Federal officials, representatives from Tribal governments, and State officials. These periodic briefs promoted the flow of information to interested stakeholders and advanced the DOE's goal of supporting the siting and licensing efforts of states and compacts.

- Workshops

The Program conducted 39 workshops attended by 658 people during FY 1997. Many of these workshops were developed to meet specialized State and compact region information needs. The DOE's National Program staff is considered the premier source of practical and unbiased information related to the practical considerations of low-level radioactive waste disposal siting and licensing. The workshop format enables attendees to participate and receive immediate feedback on the methods used during the session. The following workshops were conducted:

- $\quad$ How to Survive an Adjudicatory Public Hearing

- $\quad$ Low-Level Waste Disposal Rate Review

- $\quad$ Media Relations

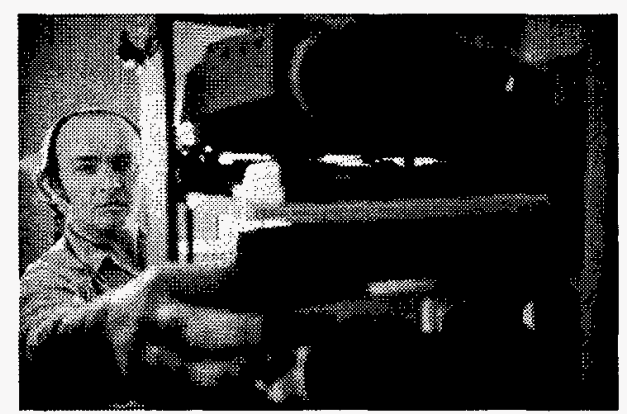


- Performance Assessment

- Radiation and Low-Level Waste Management Fundamentals

- $\quad$ Environmental Monitoring

- $\quad$ Risk Communication, Assessment, and Management

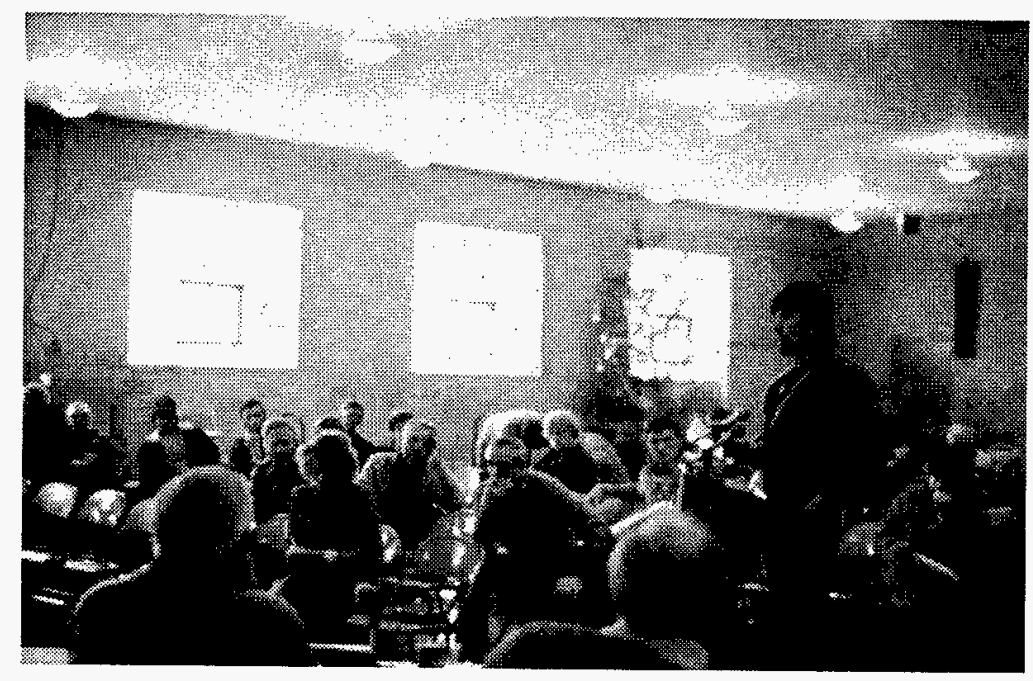

- Radioactive Materials Transportation

- Volunteer Low-Level Waste Siting Process

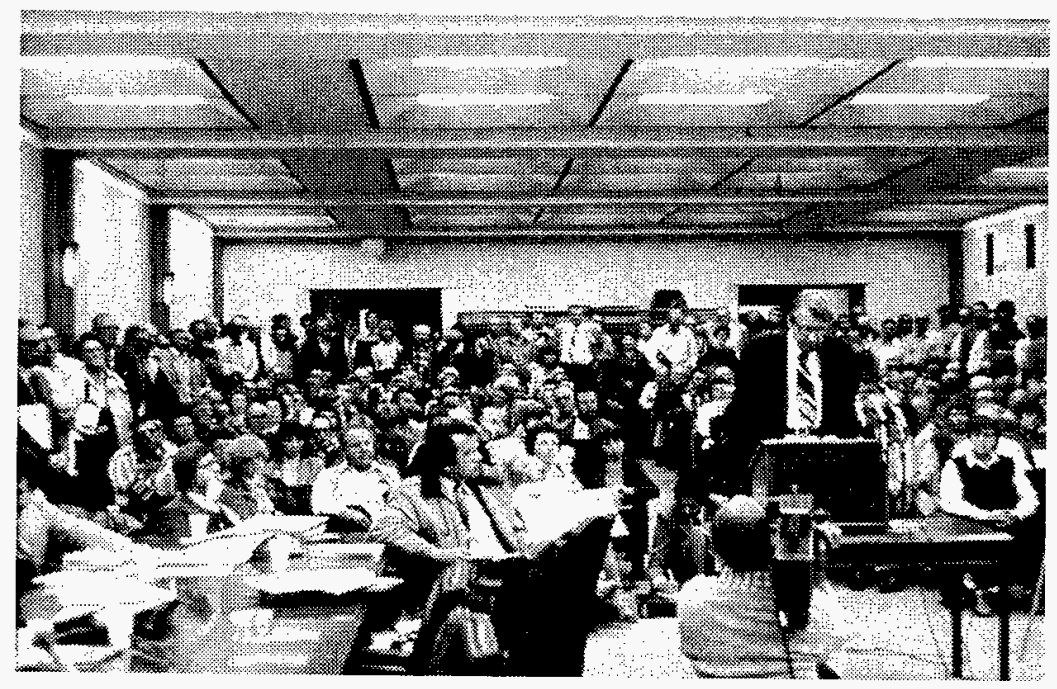




\section{General Technical Support}

The National Program provides a mechanism to exchange pertinent information among states, compact regions, Federal agencies, LLW generators and brokers, and legislators on the development of new LLW disposal capacity and management techniques. Excluding the workshops that were discussed earlier in this report, the National Program hosted and participated in over 54 meetings and national conferences in Fiscal Year 1997, enhancing the DOE's position as the leading technology and information source for radioactive waste management. The National Program's focus at conferences on LLW is towards providing an agenda that includes presentations and discussions that are interesting, informative, and directed toward problem solving. Selected individual tasks in this group include:

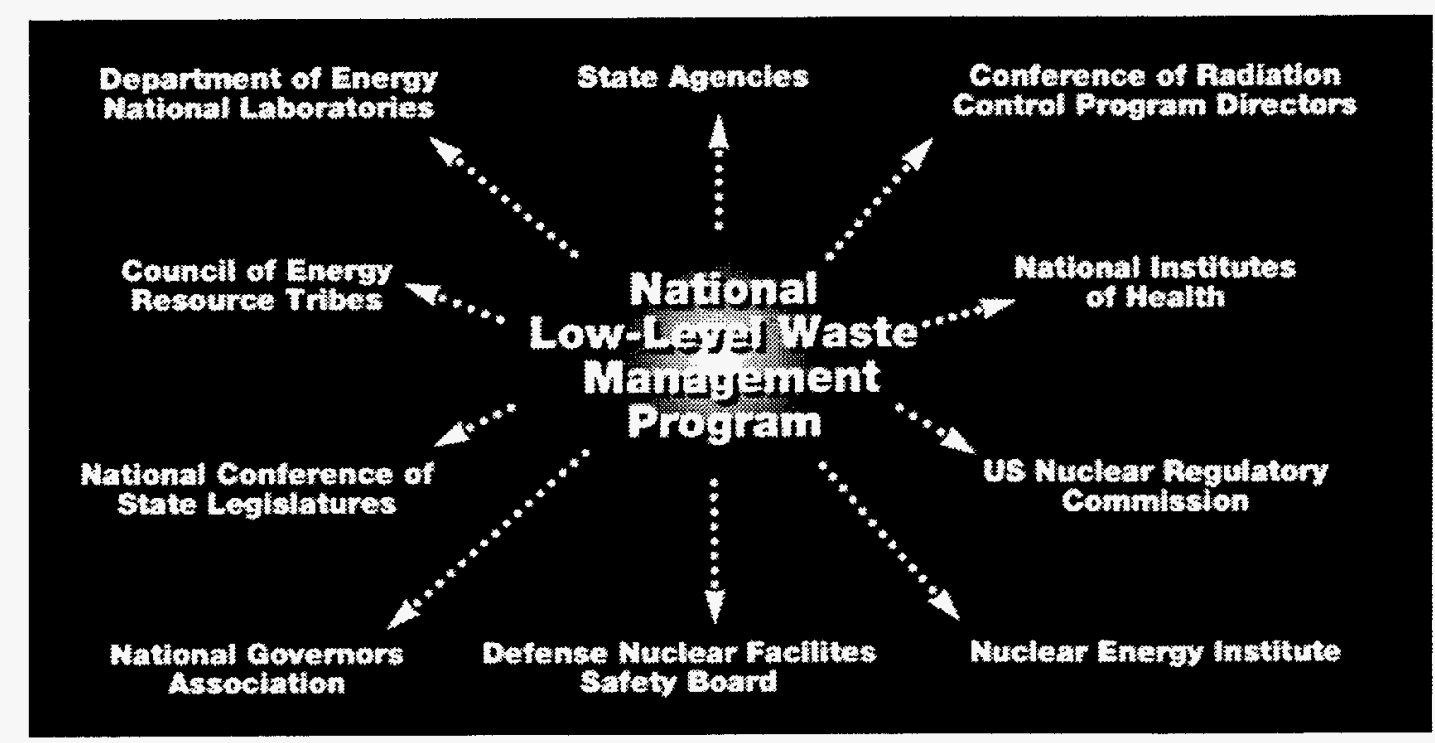

- Staff on the National Program attended the $9^{\text {th }}$ National Technology Information Exchange Workshop on August 26-28, 1997, in Idaho Falls, Idaho. Approximately 350 people attended this session that is considered one of the premier annual events for introducing new technologies and innovative technology applications.

- Demonstration testing of the Mobile Low-Level Waste Verification System was successfully completed on March 5-6, 1997, satisfying a Lockheed-Martin Idaho Technologies Company (LMITCO) cost-plus-award-fee milestone due by the end of March, 1997. The system was developed under a cost-share contract between LMITCO and WMG, Inc., to provide a rapid, non-intrusive method for verifying the radionuclide contents of low-level waste packages. The demonstration testing was performed using commercial nuclear power plant wastes at the Barnwell, South Carolina, low-level radioactive waste disposal facility. Preliminary data comparisons showed good agreement between the system test data and the prior analytical results for the waste packages tested. The project is recognized as one that not only supports the movement of technology developed in a National Laboratory to the private sector, but was also developed cooperatively using private sector finances and technology. 
- National Program staff chaired a session at the ASME Mixed Waste Symposium on August 18-21,1997, in Baltimore, Maryland. The well-attended session featured speakers from states/compact regions, the National Institutes of Health, the Environmental Protection Agency, and the commercial nuclear industry.

- Staff on the National Program attended the $7^{\text {th }}$ Annual Department of Defense LLRW Generators Meeting on February 18-20, 1997, in Norfolk, Virginia. The DOE is recognized by the DoD as a premier information source for low-level radioactive waste management and has been invited to participate in future conferences.

- The Council of Energy Resource Tribes and the National Program staff developed a booklet entitled Evaluating Proposals for Siting LLW Facilities in Indian Country. This booklet explores the cultural issues affecting the decision-making process in tribal governments and how proposals for siting LLW facilities are viewed by tribal decision-makers.

- The National Program published the report Environmental Monitoring Report for Commercial Low-Level Radioactive Waste Disposal Sites (1960s-1990s), $D O E / L L W-241$. This report was completed at the request of the Conference of Radiation Control Program Directors, Committee E-5, and represents the first environmental monitoring document integrating the results from the commercial facilities.

- National Program staff attended the International Isotope Society Mixed Waste Symposium on October 24, 1996, in Mystic, Connecticut. The thrust of the meeting was to explore possible solutions for mixed waste containing tritium and Carbon-14. The success of the meeting prompted ongoing discussions with the Environmental Protection Agency to examine potential avenues of regulatory relief.

- Program staff attended the first meeting of an Assured Isolation working group in Brighton, MA. Representatives from CT, MA, NJ, NC, NY, MI, and FL participated in discussions focusing on licensability and viability in meeting the requirements of the Low-Level Waste Policy Amendments Act.

- National Program staff prepared a presentation for the National Conference of State Legislatures Low-Level Waste Working Group meeting in Philadelphia, Pennsylvania on August 8, 1997. Program liaisons attended over 20 similar compact and advisory committee meetings and provided information on request. The Conference is increasingly involved in evaluating LLW policy issues and has been relying on the NLLWMP for its technical information needs. 
- On December 11, 1996, National Program staff provided a presentation on assured isolation to the Low-Level Radioactive Waste Working Group of the National Conference of State Legislatures. Representatives from the states of New Jersey and Connecticut attended the meeting as well as officials from the Nuclear Regulatory Commission.

- The National Program presented a report at the Assembly on State Issues in San Francisco, California, on April 4, 1997. The report focused on public participation efforts pursued by states as they attempt to open new disposal facilities.

- National Program staff presented the draft process on evaluating low-level radioactive waste forms and containers in accordance with the U.S. NRC Branch Technical Position on Waste Form at the International

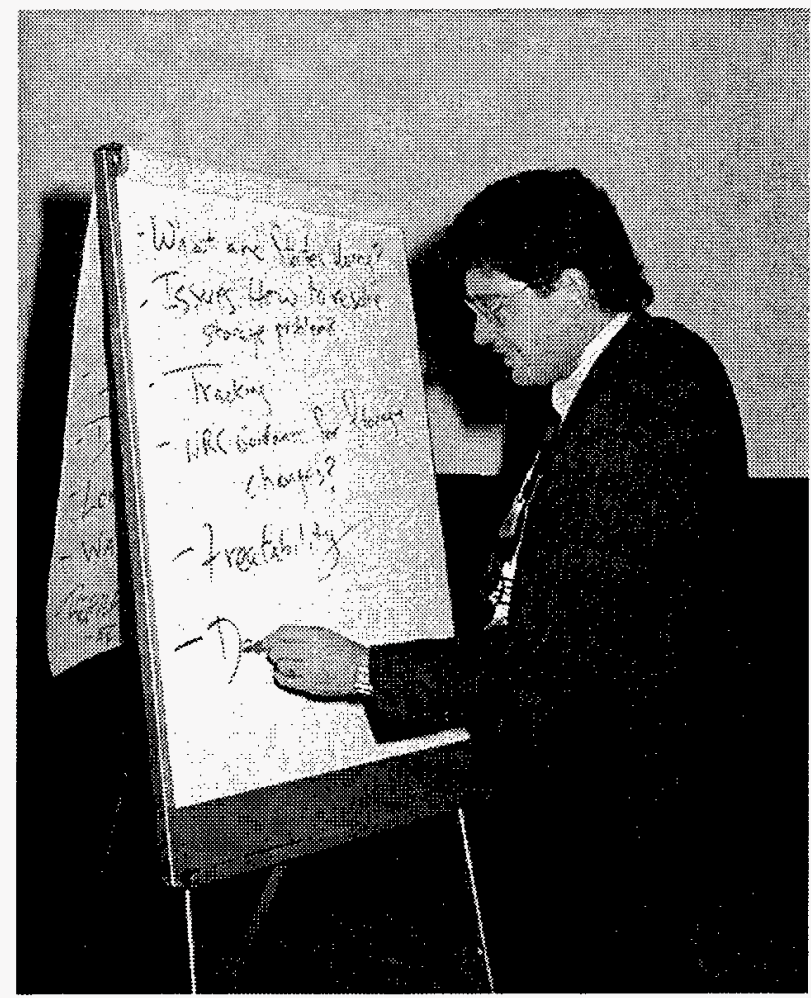
Low-Level Waste Conference and Exhibit Show '97. The Electric Power Research Institute sponsored the Exhibit on July 21-23, 1997. The draft process was favorably received by waste processing vendors.

- The 1996 State-by-State Assessment of Low-Level Radioactive Wastes Received at Commercial Disposal Sites (DOE/LLW-243) was prepared and distributed. The report was published by the $9 / 30 / 97$ milestone date and was made available on the NLLWMP website. This report provides information about LLW disposed of by states at commercial LLW disposal facilities, and also provides summary data from 1986 through 1996. This report is an important planning tool for states and compact regions for future LLW disposal.

- The National Program published the report Selected Radionuclides Important to Low-Level Radioactive Waste Management, DOE/LLW-238. This report is a compilation of previous reports on individual radionuclides and is a useful technical reference for facility performance modelers.

- The National Program published the report A Comparison and Cross Reference of Commercial Low-Level Radioactive Waste Acceptance Criteria, DOE/LLW-239. This report provides the first integrated look at the waste acceptance criteria for differing low-level radioactive waste disposal facilities.

- The National Program published the report Commercially-Available Low-Level Radioactive and Mixed Waste Treatment Technologies, DOE/LLW-240. The 
National Program published this report, which has been used extensively within the DOE Complex to identify cost-saving private alternatives to onsite treatment or technology development.

\section{Data Management}

The National Program maintains a comprehensive LLW management data base system that states, compact regions, DOE, and other Federal agencies may use to conduct analyses, make decisions, and apply in other special situations.

- Data Acquisition

Manifest records for LLW disposal shipments for the year 1996 were obtained from commercial LLW disposal site operators (with the exception of Envirocare of Utah) and incorporated into the Manifest Information Management System (MIMS). The Manifest Information Management System was made accessible to outside entities via the Internet. MIMS is the only system in the United States with centralized information on commercial LLRW shipments.

- Customer Support

Program staff recorded approximately 2,000 hits on the Manifest Information Management (MIMS) homepage in the past year. The information was used as supporting data in states' annual reports, for answers to queries from the public, educational briefings, and in several newspaper articles. Information was developed and transmitted to the Integrated Data Base (IDB) program detailing the commercial LLW disposed in 1996. Other supporting data were also transmitted to the IDB program for LLW section of the Integrated Database Report-1996: U.S. Spent Nuclear Fuel and Radioactive Waste Inventories, Projections, and Characteristics. This report was published in December, 1997 for the U.S. DOE Office of Environmental Restoration and Waste Management. Data were also supplied for the Annual DOE Report to Congress.

- The Program developed and released Version II of the PC-based Low-Track software to assist states and compact regions in tracking stored LLW. This version included the Connecticut State survey forms that allow users to meet the state reporting requirements electronically. Low-Track supports the U.S. Nuclear Regulatory Commission's requirements for a uniform national manifest system for

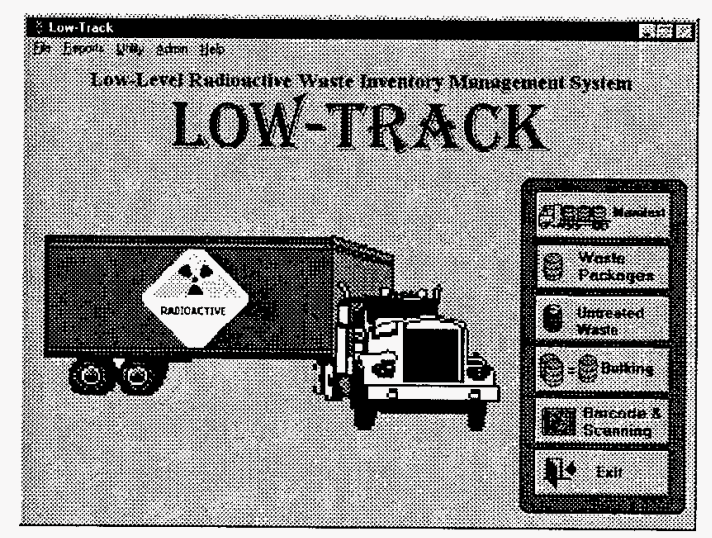


low-level radioactive waste. Over 200 Low-Track users were on file with the National Program at the end of FY 1997 and have expressed interest in the Program supporting a Users Group.

\section{Host State Technical Coordinating Committee}

The Host State Technical Coordinating Committee (TCC) provides an opportunity for technical representatives from states developing new LLW disposal facilities to coordinate and promote the exchange of information between states, to address technical issues of mutual interest to states, and to focus and suggest priorities on research and development activities. The National Program supports the TCC and moderates the meetings held each year. Meetings were held in Covington, Kentucky, Laughlin, Nevada, Salt Lake City, Utah, and Buffalo, New York. This fiscal year the TCC addressed the following topics and issues: position-sensitive radiation detection instrumentation, an overview of the former Maxey Flats low-level waste disposal facility, cost studies being performed for Connecticut and New Jersey, surviving an adjudicatory hearing, vitrification of low-level radioactive waste, icon-driven performance assessment systems, and an overview of the proposed Ward Valley disposal facility.

\section{Low-Level Radioactive Waste Forum}

The Forum is an association of State and compact region representatives, supported by a DOE grant, established to help implement the LLRWPAA. The Forum held three meetings during the fiscal year. The National Program continues to foster a relationship with the Forum and coordinates activities for effective cost controls. The National Program continues to support the Forum by providing Forum notes and announcements to special interest groups.

\section{GTCC LLW PROGRAM SUPPORT}

The program support task provides information, planning, project management, and technical support for the day-to-day operation of the Greater Than Class C (GTCC) LLW Program. Key accomplishments under this task include the following:

- Prepared a plan and began implementation for a GTCC demonstration storage project at the Nevada Test Site. Issues explored included volume reduction using dissolution techniques, storage in Idaho, and storage at Savannah River.

- $\quad$ Prepared a letter of response to Governor Miller of Nevada concerning DOE plans to site a demonstration storage project for a small volume of GTCC waste.

- Prepared a GTCC status presentation for a university and test reactor users group

- Prepared a proposed report to Congress that summarizes the tentative Program strategy revisions.

- Responded to several ad hoc requests concerning GTCC policy. 
- Supported the Yucca Mountain EIS data call concerning GTCC waste and special case waste inventories by attending a meeting in Las Vegas, Nevada, on February 4, 1997 with the Yucca Mountain Project personnel. Subsequent to the meeting, Program staff transmitted additional information to the Yucca Mountain Project team, including additional copies of Greater-Than-Class-C Low-Level Radioactive Waste Characterization: Estimated Volumes, Radionuclide Activities, and Other Characteristics, DOE/LLW-114.

- Developed work scope white papers for the GTCC program that focused on three distinctly different methods for handling waste generated during the decontamination and decommissioning of three nuclear power stations. 


\section{APPENDIX A}

\section{NATIONAL PROGRAM WORK PACKAGE COST SUMMARY}

The activities performed by the National Program are categorized into four work packages:

General Assistance, DOE Support, Specific Technical Assistance, and the Greater-Than-Class-C Low-Level Waste Program. Funding levels are indicative of the level of activity for each work package.

General Technical Support Work Package.............................................................\$1,404,250

DOE Support Work Package. $\$ 896,867$

Specific Technical Assistance Work Package. $\$ 941,935$

GTCC LLW Program Work Package. $\$ 90,645$

The total actual Program expenditure for Fiscal Year 1997 was \$3,333,697. 


\section{M98052579

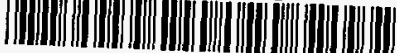

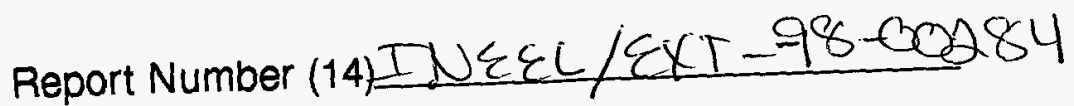

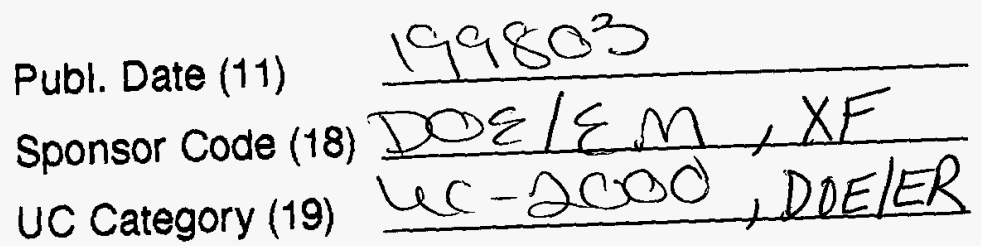

